\title{
Identifikasi Keragaman Gen FTO Pada Bangsa Sapi Potong Indonesia
}

\author{
Sutikno $^{1}$, Rudy Priyanto ${ }^{2}$, Cece Sumantri ${ }^{2}$, Jakaria ${ }^{2 *}$ \\ ${ }^{1}$ Jurusan Peternakan Sekolah Tinggi Pertanian Kutai Timur (STIPER KUTIM) \\ Jl. Soekarno-Hatta no 1, Sangatta, Kutai Timur, Kalimantan Timur 75387 \\ ${ }^{2}$ Departemen Ilmu Produksi dan Teknologi Peternakan, Fakultas Peternakan, IPB \\ Jl. Agatis Kampus IPB Dramaga, Bogor, Jawa Barat 16680 \\ *Email korespondensi: jakaria_karman@yahoo.co.id
}

(Diterima: 21-02-2019; disetujui 20-04-2019)

\begin{abstract}
ABSTRAK
Gen FTO berfungsi sebagai regulasi homeostasis, deposisi lemak dan pengaturan obesitas. Penelitian ini bertujuan untuk mengidentifikasi polimorfisme SNP g.125550A>T di ekson 3 gen FTO pada bangsa sapi potong Indonesia. Sampel darah diperoleh dari 209 ekor sapi, terdiri atas sapi bali (44), madura (20), Pesisir (20), katingan (20), Peranakan ongole (PO) (22), Pasundan (20), Sumba Ongole (SO) (11), brahman (20), simental (15), dan limousin (18). Polimorfisme gen FTO dianalisis menggunakan metode PCR-RFLP (HpyCH4III) dan direct sequencing. Hasil genotiping SNP g. $125550 \mathrm{~A}>\mathrm{T}$ adalah polimorfik (genotipe AA, AT, dan TT) pada sapi madura, pesisir, katingan, PO, pasundan, SO, brahman, simental, dan limousin. Frekuensi alel A dan T masing-masing adalah 0,70, $0,68,0,84,0,89,0,70,0,86,0,90,0,73,0,69$ dan $0,30,0,33,0,16,0,11,0,30,0,14,0,10,0,27,0,31$. Nilai Ho dan He masing-masing adalah 0,60-0,14 dan 0,44-0,18 serta dalam keseimbangan Hardy-Weinberg (P>0.05). Sementara pada sapi bali bersifat monomorfik hanya bergenotipe AA. Hasil sekuensing SNP g.125550A $>\mathrm{T}$ ditemukan mutasi tranvesi A menjadi T pada posisi nukleotida g.125550. Berdasarkan hasil penelitian ini, dapat disimpulkan bahwa SNP 125550A>T gen FTO beragam dan berpotensi dijadikan marka genetik untuk kualitas daging pada bangsa sapi potong Indonesia.
\end{abstract}

Kata Kunci: gen FTO, PCR-RFLP, Sapi, SNP g.125550A>T

\section{ABSTRACT}

The FTO gene functions as regulation of homeostasis, fat deposition and regulation of obesity. This study aimed to identify the polymorphism of SNP g.125550A>T in exon 3 of FTO gene in Indonesian beef cattle. Blood samples were collected from 209 cattle, including bali (44), madura (20), pesisir (20), katingan (20), PO (22), pasundan (20), SO (11), brahman (20), simental (15), and limousin (18). Polymorphism of the FTO gene was analyzed using PCR-RFLP (HpyCH4III) and direct sequencing methods. The results of genotyping SNP g.125550A $>\mathrm{T}$ was polymorphic (AA, AT and TT genotypes) in madura, pesisir, katingan, $\mathrm{PO}$, pasundan, $\mathrm{SO}$, brahman, simental, and limousin cattle. The frequency of $\mathrm{A}$ and $\mathrm{T}$ alleles were $0,70,0,68,0,84,0,89,0,70,0,86,0,90,0,73,0,69$ and $0,30,0,33$, $0,16,0,11,0,30,0,14,0,10,0,27,0,31$ respectively. The values of Ho and He were $0,60-0,14$ and $0,44-$ 0,18 respectively and in Hardy-Weinberg equilibrium $(\mathrm{P}>0,05)$. While in Bali cattle was monomorphic (AA genotype). Results of sequencing SNP g.125550A $>$ T of the FTO gene found a transverse mutation A to $\mathrm{T}$ at the nucleotide position g.125550. As a result of this study, it can be concluded that SNP $125550 \mathrm{~A}>\mathrm{T}$ of the FTO gene was diverse and potentially used as genetic markers for meat quality in Indonesian beef cattle.

Keywords: cattle, FTO gene, PCR-RFLP, SNP g.125550A>T 


\section{PENDAHULUAN}

Kekayaan sumber daya genetik ternak (SDGT) yang dimiliki Indonesia sangat melimpah, salah satunya sapi potong (pedaging). Indonesia memiliki 8 bangsa sapi potong antara lain: sapi bali, madura, aceh, sumbawa, pesisir, peranakan ongole (PO), jabres, dan sumba ongole (SO). Kekayaan SDGT perlu dilestarikan, dikembangkan dan dimanfaatkan secara berkelanjutan demi meningkatkan pendapatan dan kesejahteraan peternak serta memperkuat ketahanan pangan nasional. Kebijakan pengelolaan SDGT yang berkelanjutan merujuk kepada tiga pendekatan, yaitu: pemurnian dan konservasi ternak, persilangan ternak, dan pengembangan bangsa baru.

Sapi potong Indonesia berpotensi untuk dikembangkan menjadi sapi potong unggul melalui proses seleksi dan persilangan. Dewasa ini telah berkembang seleksi berdasarkan marka genetik atau disebut marker assisted selection (MAS) yang hasilnya lebih akurat, efektif dan efisien (Matukumalli et al., 2009). Proses seleksi dapat dilakukan pada kandidat gen-gen yang berasosiasi dengan sifat pertumbuhan dan kualitas daging. Salah satu gen yang potensial untuk diseleksi yaitu gen fat mass and obesity associated (FTO) (Wei et al., 2011; Chung, 2014).

Gen FTO terletak pada kromosom 18 yang terdiri atas 9 ekson dan 8 intron. Gen FTO berfungsi untuk regulasi homeostasis, deposisi lemak dan pengaturan obesitas. Informasi polimorfisme nukleotida tunggal atau single nucleotide polymorphisms (SNP) g.125550A > T di ekson 3 gen FTO berpengaruh terhadap skor marbling pada sapi hanwoo. (Chung, 2014). Gen FTO selama ini belum diteliti pada sapi potong Indonesia. Penelitian ini bertujuan mengidentifikasi SNP g.125550A >T di ekson 3 gen FTO pada bangsa sapi potong Indonesia.

\section{MATERI DAN METODE}

\section{Sampel Sapi Penelitian}

Penelitian dilakukan di laboratorium genetika molekuler ternak, Fakultas Peternakan, Institut Pertanian Bogor. Sampel darah sapi yang digunakan sebanyak 209 ekor. Darah berasal dari koleksi laboratorium genetika molekuler ternak perwakilan sapi potong di Indonesia yang terdiri atas: sapi bali, madura, pesisir, katingan, PO, pasundan, SO, brahman, simental, dan limousin (Tabel 1).

Tabel 1. Jumlah, bangsa, tahun koleksi dan lokasi pengambilan sampel darah sapi potong yang digunakan dalam penelitian

\begin{tabular}{clccl}
\hline No & \multicolumn{1}{c}{ Bangsa } & $\begin{array}{r}\text { Jumlah } \\
\text { sampel }\end{array}$ & Tahun Koleksi & \multicolumn{1}{c}{ Lokasi } \\
\hline 1 & Sapi Bali & 44 ekor & 2015 & Pulau Bali \\
2 & Sapi Madura & 20 ekor & 2011 & Pulau Madura \\
3 & Sapi Pesisir & 20 ekor & 2006 & Sumatera Barat \\
4 & Sapi Katingan & 19 ekor & 2010 & Kalimantan Tengah \\
5 & Sapi PO & 22 ekor & 2006 & Jawa Barat \\
6 & Sapi Pasundan & 20 ekor & 2014 & Jawa Barat \\
7 & Sapi SO & 11 ekor & 2006 & Nusa Tenggara Timur \\
8 & Sapi Brahman & 20 ekor & 2006 & Jawa Barat \\
9 & Sapi Simental & 15 ekor & 2006 & Jawa Timur \\
10 & Sapi Limousin & 18 ekor & 2006 & Jawa Timur \\
\hline & Total & 209 ekor & & \\
\hline
\end{tabular}

\section{Ekstraksi dan Amplifikasi DNA}

Sampel darah diambil dari vena jugularis dan disimpan dalam tabung vaccutainer yang mengandung etanol absolut sebagai antikoagulan. DNA genom diisolasi menggunakan metode fenol-cloroform yang dijelaskan oleh (Sambrook dan Russel 2001). Primer yang digunakan untuk amplifikasi gen FTO adalah: (forward: 5'-TCCTCAAGCTCAACAGCTAC-3', Reverse: 5'-GGTTCCTCTTTCAGGTATGG-3'). Primer dirancang berdasar-kan sekuen Genbank dengan nomor akses HM777022.1 mengguna- kan software MEGA7 dan dievaluasi secara online menggunakan PCR Primer Stats (www.bioinformatics.org).

Amplifikasi fragmen gen menggunakan mesin Thermal Cycler merk Esco. Pereaksi Polymerase Chain Reaction (PCR) terdiri atas: sampel DNA $1 \mathrm{uL}, 7,5 \mathrm{uL}$ promega green master mix, 6,1 uL DW, 0,2 uL primer forward, dan 0,2 $\mathrm{uL}$ primer reverse. Suhu amplifikasi DNA terdiri atas: predenaturasi $95^{\circ} \mathrm{C}$ selama 5 menit, denaturasi $95^{\circ} \mathrm{C}$ selama 20 detik, annealing $60^{\circ} \mathrm{C}$ selama 30 detik, ekstensi $72^{\circ} \mathrm{C}$ selama 30 
detik, ekstensi akhir $72^{\circ} \mathrm{C}$ selama 5 menit. Tahapan denaturasi sampai ekstensi diulang sebanyak 35 kali.

\section{Penentuan Genotipe}

Penentuan genotipe gen FTO menggunakan metode restriction fragment lenght polymorphisms (RFLP) dan sekuensing. RFLP dilakukan menggunakan enzim restriksi HpyCH4III (ACN|GT). Hasil RFLP divisualisasi menggunakan gel agarose $2 \%$ dengan buffer $0,5 \times \mathrm{TBE}$ (tris borax EDTA) yang diwarnai dengan fluorosafe, gel difoto menggunakan UV Transiluminator.

Sekuensing dilakukan pada sampel sapi Bali dan Simental yang mewakili genotipe berbeda sebanyak dua sampel untuk setiap genotipe. Sekuensing dilakukan dengan menggunakan mesin sekuenser (ABI Prims 3100-Avant Genetic Analyzer) pada fragmen primer forward melalui jasa perusahaan sekuensing 1st Base di Selangor, Malaysia.

\section{Analisis Data}

Frekuensi Genotipe dan Alel; frekuensi genotipe merupakan rasio dari jumlah suatu genotipe terhadap jumlah populasi. Frekuensi genotipe dihitung berdasarkan rumus Nei dan Kumar (2000) sebagai berikut:

$$
\mathrm{X}_{\mathrm{ii}}=\mathrm{n}_{\mathrm{i} /} / \mathrm{N} \text {, }
$$

Keterangan:

$\mathrm{X}_{\mathrm{ii}}=$ Frekuensi genotipe ke ii, $\mathrm{n}_{\mathrm{ii}}=$ Jumlah sampel bergenotipe ii dan $\mathrm{N}=$ Jumlah sampel.

Frekuensi alel merupakan rasio suatu alel terhadap keseluruhan alel pada suatu lokus dalam populasi. Frekuensi alel dihitung berdasarkan dengan rumus:

$$
\mathrm{X}_{\mathrm{i}}=\left(2 \mathrm{n}_{\mathrm{ii}}+\sum \mathrm{n}_{\mathrm{ij}}\right) / 2 \mathrm{~N}
$$

Keterangan:

$\mathrm{X}_{\mathrm{i}}=$ frekuensi alel ke $\mathrm{i}, \mathrm{n}_{\mathrm{ii}}=$ jumlah sampel bergenotipe ii, $n_{i j}=$ jumlah sampel bergenotipe $\mathrm{ij}, \mathrm{N}=$ jumlah total sampel (Nei \& Kumar, 2000).

Heterozigositas; keragaman genetik dapat diketahui melalui estimasi frekuensi heterozigositas pengamatan $\left(\mathrm{H}_{\mathrm{o}}\right)$ yang diperoleh dari masing-masing populasi dihitung dengan rumus:

$$
\mathrm{H}_{o}=\sum_{i \neq j} \frac{n i j}{N}
$$

Keterangan:

$\mathrm{H}_{\mathrm{o}}=$ heterozigositas pengamatan, $\mathrm{n}_{\mathrm{ij}}=$ jumlah sampel heterozigot, $\mathrm{N}=$ jumlah sampel yang diamati.

Heterozigositas harapan $\left(\mathrm{H}_{\mathrm{e}}\right)$ dihitung dengan rumus:

$$
H e=1-\sum_{i=1}^{q} x_{i}^{2}
$$

Keterangan:

$\mathrm{H}_{\mathrm{e}}=$ heterozigositas harapan, $\mathrm{x}_{\mathrm{i}}=$ frekuensi alel, $\mathrm{q}=$ jumlah alel (Nei \& Kumar 2000)

\section{Keseimbangan Hardy-Weinberg (KHW)}

KHW dihitung dengan rumus:

$$
X^{2}=\sum \frac{(O-E)^{2}}{E}
$$

Keterangan:

$\mathrm{X}^{2}=$ chi-kuadrat, $\mathrm{O}=$ jumlah pengamatan genotipe ke I, $\mathrm{E}=$ jumlah harapan genotipe ke $\mathrm{i}$. Derajat bebas $(\mathrm{db})$ untuk uji KHW db $=$ jumlah kemungkinan genotipe - jumlah alel (Allendorf et al., 2013).

\section{Analisis Hasil Sekuensing}

Hasil sekuensing gen FTO dianalisis dengan software FinchTV dan BioEdit (Hall 2011). Penentuan SNP menggunakan program Molecular Evolutionary Genetic Analysis 7 (MEGA 7) (Tamura et al., 2011).

\section{HASIL DAN PEMBAHASAN}

\section{Amplifikasi Dan Variasi SNP g.125550A $>$ T Gen FTO Pada Sapi Potong Indonesia}

Gen FTO berhasil diamplifikasi pada suhu annealing $60{ }^{\circ} \mathrm{C}$ selama 30 detik menggunakan mesin thermal cycler merk esco. Produk PCR gen FTO yang dihasilkan sebesar 241 bp. Hasil penelitian ditemukan tiga genotipe pada bangsa sapi potong Indonesia yaitu genotipe AA, AT dan TT seperti tersaji pada Gambar 1. Alel A tidak terpotong oleh enzim restriksi $\mathrm{HpyCH} 4 \mathrm{III}$ (ACN|GT) ditandai dengan 1 pita 241 bp, sedangkan alel $\mathrm{T}$ yang terpotong menghasilkan 2 pita sebesar $171 \mathrm{bp}$ dan $70 \mathrm{bp}$. Variasi SNP g.125550A $>$ T gen FTO terletak di ekson 3 telah dilaporkan sebelumnya pada sapi Hanwoo dimana sapi yang bergenotipe AA dan TT memiliki skor marbling yang lebih tinggi dibanding yang bergenotipe AT (Chung, 2014). 


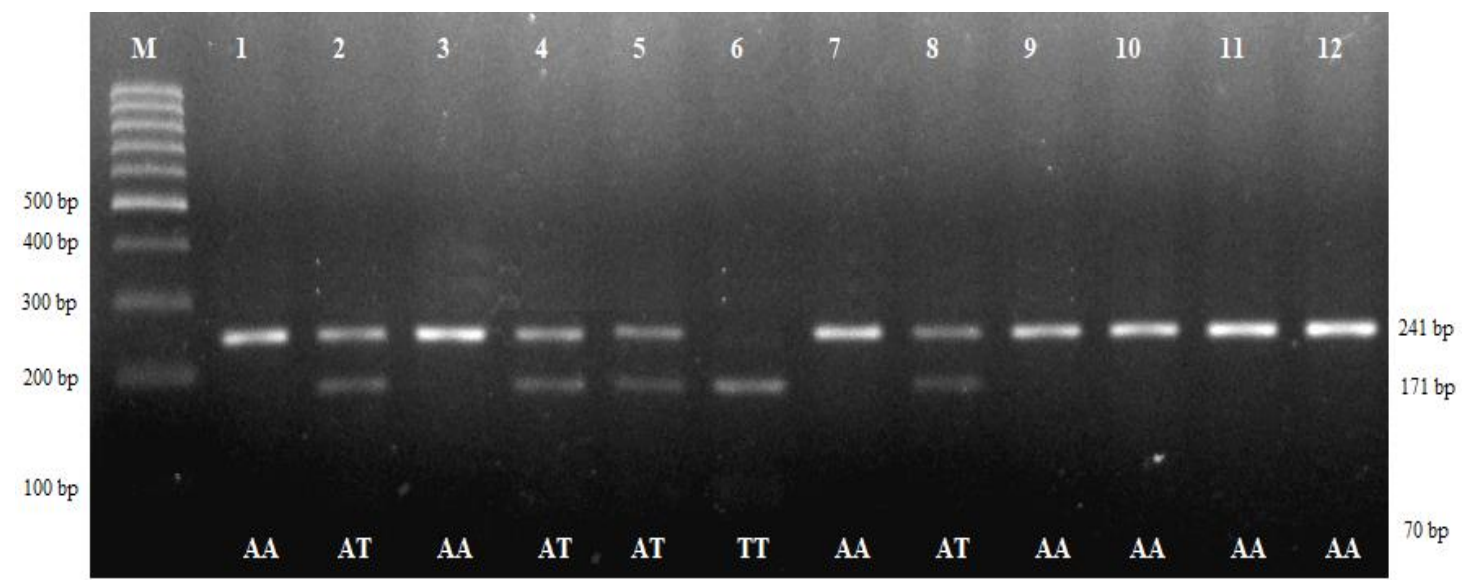

Gambar 1. Hasil PCR-RFLP SNP g.125550A>T pada ekson 3 gen FTO menggunakan enzim restriksi HpyCH4III pada gel agarose 2\%. M = marker DNA 100 bp; 1 s/d $12=$ sampel sapi potong; genotipe AA (241 bp), AT (241, 171 dan 70 bp) dan TT (171 dan $70 \mathrm{bp}$ ).

\section{Frekuensi Genotipe dan Alel SNP g.125550A>T Gen FTO Pada Sapi Potong Indonesia}

Hasil penelitian ini menunjukkan bahwa SNP g.125550A $>$ T gen FTO bersifat polimorfik pada sapi madura, pesisir, katingan, PO, pasundan, SO, brahman, simental dan limousin karena frekuensi alel yang diperoleh lebih dari 0.01 (Nei \& Kumar, 2000, Allendroft et al., 2013). Frekuensi genotipe dan alel tersaji pada
Tabel 2. Frekuensi alel A tinggi pada bangsa sapi potong Indonesia yang diteliti diduga akibat seleksi dan manajemen perkawinan yang dilakukan oleh peternak. Penelitian-penelitian sebelumnya membuktikan terjadi asoasiasi antara variasi gen FTO dengan deposisi lemak intramuskular dan tebal lemak punggung pada sapi lokal Cina (ekson 5), skor marbling pada sapi Hanwoo (ekson 3) (Wei et al., 2011; Chung, 2014).

Tabel 2. Frekuensi genotipe dan frekuensi alel SNP g.125550A>T gen FTO pada sapi potong Indonesia

\begin{tabular}{lcccccc}
\hline \multirow{2}{*}{ Bangsa sapi } & Jumlah Sampel & \multicolumn{3}{c}{ Frekuensi Genotipe } & \multicolumn{2}{c}{ Frekuensi Alel } \\
\cline { 3 - 7 } & & AA & AT & TT & A & T \\
\hline Sapi bali & 44 ekor & 1,00 & 0,00 & 0,00 & 1,00 & 0,00 \\
Sapi madura & 20 ekor & 0,40 & 0,60 & 0,00 & 0,70 & 0,30 \\
Sapi pesisir & 20 ekor & 0,45 & 0,45 & 0,10 & 0,68 & 0,33 \\
Sapi katingan & 19 ekor & 0,68 & 0,32 & 0,00 & 0,84 & 0,16 \\
Sapi PO & 22 ekor & 0,82 & 0,14 & 0,05 & 0,89 & 0,11 \\
Sapi pasundan & 20 ekor & 0,45 & 0,50 & 0,05 & 0,70 & 0,30 \\
Sapi SO & 11 ekor & 0,73 & 0,27 & 0,00 & 0,86 & 0,14 \\
Sapi brahman & 20 ekor & 0,80 & 0,20 & 0,00 & 0,90 & 0,10 \\
Sapi simental & 15 ekor & 0,47 & 0,53 & 0,00 & 0,73 & 0,27 \\
Sapi limousin & 18 ekor & 0,44 & 0,50 & 0,06 & 0,69 & 0,31 \\
\hline
\end{tabular}

Hasil analisis SNP g.125550A>T gen FTO pada sapi Bali bersifat monomorfik karena hanya ditemukan satu alel yaitu alel A (Nei \& Kumar 2000, Allendroft et al., 2013). Sapi Bali merupakan sapi asli Indonesia hasil domestikasi dari banteng (Bibos banteng) (Purwantara et al., 2012). Hasil penelitian-penelitian sebelumnya menunjukkan bahwa pada sapi Bali (Bos javanicus) memiliki perbedaan posisi SNP dengan bangsa sapi Bos taurus maupun bangsa sapi Bos indicus. Beberapa penelitian yang menemukan posisi SNP baru pada sapi Bali seperti pada gen calpain-1 (CAPN1) (Pratiwi et al. 2016), gen myogenic factor 5 (Myf5), gen myostatin (MSTN) (Khasanah et al., 2016), gen stearoyl-CoA denaturase (SCD) (Alwiyah et al. 
2016), gen thyroglobulin 5 (TG5) (Anwar et al. 2017), dan gen endothelial differentiation sphingolipid G-protein-coupled receptor 1 (EDG1) (Sutikno et al., 2018).

\section{Nilai Heterozigositas dan Keseimbangan Hardy-Weinberg (KHW)}

Hasil analisis nilai heterozigositas pengamatan (Ho) dan nilai heterozigositas harapan $(\mathrm{He})$ dan hasil uji chi-square $\left(\chi^{2}\right)$ SNP g.125550A $>$ T gen FTO pada sapi potong
Indonesia disajikan pada Tabel 3. Hasil analaisis nilai heterozigositas pengamatan (Ho) pada sapi potong Indonesia bervariasi dari tinggi ke rendah berturut-turut sebagai berikut: sapi madura, simental, pasundan, limousin, pesisir, katingan, SO, brahman, PO. Pada sapi bali nilai Ho dan He tidak dapat dianalisis karena monomorfik. Nilai heterozigositas merupakan rataan persentase lokus heterozigot tiap individu atau rataan persentase individu heterozigot dalam populasi (Nei \& Kumar, 2000).

Tabel 3. Nilai Heterozigositas dan keseimbangan Hardy-Weinberg pada bangsa sapi potong Indonesia

\begin{tabular}{lcccc}
\hline \multirow{2}{*}{ Bangsa Sapi } & Jumlah & \multicolumn{2}{c}{ Heterozigositas } & \multirow{2}{*}{ KHW } \\
\cline { 3 - 4 } & sampel & Ho & He & \\
\hline Sapi Bali & 44 ekor & 0,00 & 0,00 & - \\
Sapi Madura & 20 ekor & 0,60 & 0,42 & $3,67^{\text {tn }}$ \\
Sapi Pesisir & 20 ekor & 0,45 & 0,44 & $0,013^{\text {tn }}$ \\
Sapi Katingan & 19 ekor & 0,32 & 0,27 & $0,668^{\text {tn }}$ \\
Sapi PO & 22 ekor & 0,14 & 0,20 & $2,296^{\text {tn }}$ \\
Sapi Pasundan & 20 ekor & 0,50 & 0,42 & $0,726^{\text {tn }}$ \\
Sapi SO & 11 ekor & 0,27 & 0,24 & $0,274^{\text {tn }}$ \\
Sapi Brahman & 20 ekor & 0,20 & 0,18 & $0,247^{\text {tn }}$ \\
Sapi Simental & 15 ekor & 0,53 & 0,39 & $1,983^{\text {tn }}$ \\
Sapi Limousin & 18 ekor & 0,50 & 0,42 & $0,571^{\text {tn }}$ \\
\hline TOTAL & 209 ekor & \multicolumn{3}{l}{} \\
\hline Ho: heterozigositas pengamatan, He: heterozigositas harapan, KHW: & &
\end{tabular}

Keragaman genetik suatu populasi dapat diukur menggunakan nilai heterozigositas (Marson et al. 2005). Nilai heterozigositas tinggi menunjukkan tingginya keragaman genetik dalam suatu populasi. Nilai heterozigositas harapan $(\mathrm{He})$ berkisar antara 0.44-0.14. Pada sapi Katingan dan sapi PO nilai Ho lebih kecil dari nilai $\mathrm{He}$, hal ini dapat dijadikan indikasi adanya derajat endogami (perkawinan dalam kelompok) sebagai akibat dari proses seleksi yang intensif (Tambasco et al. 2003).

Hasil analisis chi-square $\left(\chi^{2}\right)$ SNP g.125550A $>$ T gen FTO menunjukkan bahwa selain pada sapi Bali, variasi SNP g.125550A >T gen FTO pada bangsa sapi potong Indonesia berada dalam keadaan keseimbangan HardyWeinberg. Pada sapi Bali tidak dapat dianlisis keseimbangan Hardy-Weinbergnya karena bersifat monomorfik. Suatu populasi ternak dinyatakan berada dalam keseimbangan HardyWeinberg apabila frekuensi genotipe dan frekuensi alelnya konstan dari generasi ke generasi yang diakibatkan oleh penggabungan gamet yang terjadi secara acak dalam populasi yang besar (Allendorf et al., 2013).

\section{Hasil Sekuensing SNP g.125550A $>$ T Gen FTO Pada Sapi Potong Indonesia}

Hasil sekuensing SNP g.125550A>T gen FTO di ekson 3 pada sapi potong Indonesia tersaji pada gambar 2. Setelah dilakukan penyejajaran sekuen nukleotida dengan data GenBank (no akses AC_000175.1 dan HM777022.1) menunjukkan bahwa pada genotipe AA terjadi mutasi tranversi antara basa timin menjadi adenin ( $>$ A) pada posisi nukleotida ke 173 (dihitung dari primer forward) atau pada posisi g.125550 (dihitung dari start kodon ATG) dari total genom gen FTO (GenBank no. AC_000175.1). Mutasi berupa SNP g.125550T $>$ A merupakan mutasi nonsynonimous yaitu mutasi yang menyebabkan perubahan sekuen asam amino dari sebuah protein, dari asam amino valina (GTA) menjadi 
asam glutamat (GAA) (Brown, 2007). Perubahan asam amino ini yang diduga menyebabkan perubahan fenotipe pada sapi, dimana sapi Hanwoo yang bergenotipe homozigot AA dan TT memiliki skor marbling yang lebih tinggi dibanding yang bergenotipe heterzigot AT (Chung, 2014).

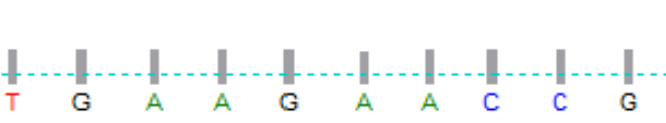

$\mathbf{A}$

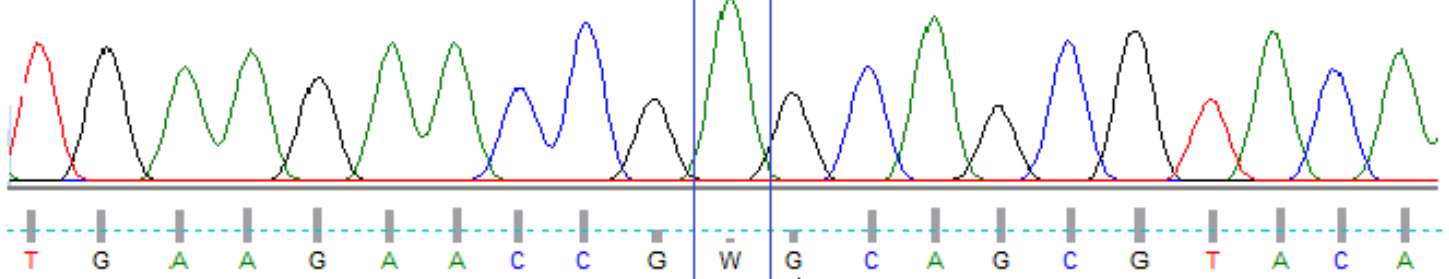

B

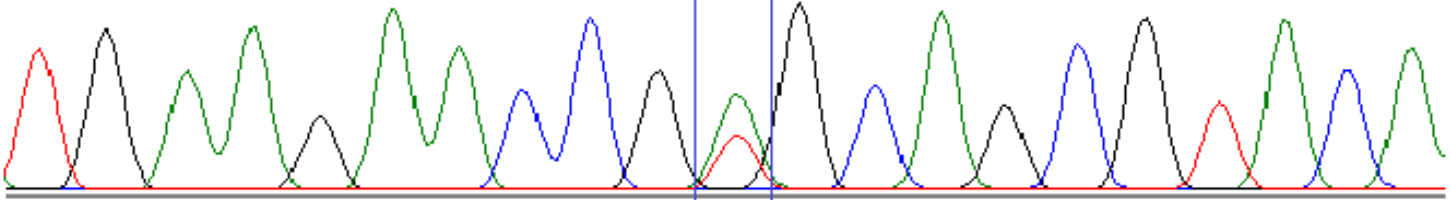

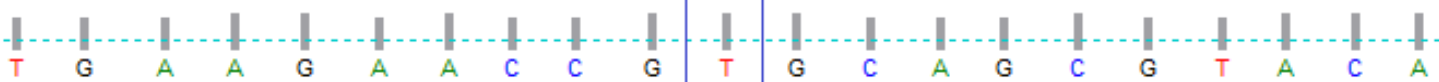

C

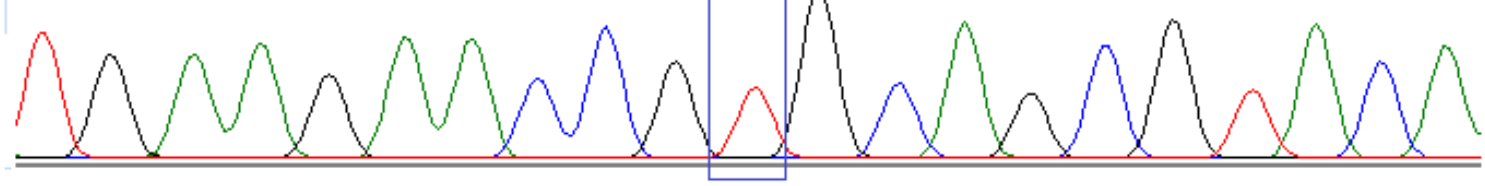

Gambar 2. Hasil sekuensing SNP g.125550A>T di ekson 3 gen FTO. A : Genotipe AA; B : Genotipe AT; C: genotipe TT; W : nukleotida A dan T.

Mutasi gen FTO pada posisi g. 125550A $>\mathrm{T}$ dikenali oleh enzim restriksi HpyCH4III (ACNIGT), dimana alel T terpotong pada posisi nukleotida ke 171 bp (dihitung dari primer forward). Mutasi transversi merupakan mutasi titik yang menyebabkan perubahan basa nitrogen tidak sejenis, contohnya perubahan basa purin dengan pirimidin $(\mathrm{G}>\mathrm{C}, \mathrm{G}>\mathrm{T}, \mathrm{A}>\mathrm{C}$, A>T) atau sebaliknya (Keller et al. 2007).

\section{KESIMPULAN}

SNP g.125550A $>\mathrm{T}$ gen FTO bersifat polimorfik pada bangsa sapi potong Indonesia yang terdiri atas: sapi madura, sapi pesisir, sapi katingan, sapi PO, sapi pasundan, sapi SO, sapi brahman, sapi simental dan sapi limousin. Sementara pada sapi bali bersifat monomorfik. Polimorfisme SNP g.125550A>T gen FTO pada ekson 3 berpotensi dijadikan marka genetik untuk sifat kualitas daging pada bangsa sapi potong Indonesia.

\section{UCAPAN TERIMA KASIH}

Penelitian ini telah dibiayai oleh hibah Penelitian Disertasi Doktor (PDD) dengan nomor kontrak 3/E1/KP.PTNBH/2019 dari
Direktorat Jenderal Penguatan Riset dan Pengembangan Kemenristekdikti tahun anggaran 2019.

\section{DAFTAR PUSTAKA}

Allendorf, F.W., G. Luikar, \& S.N. Aitken. 2013. Conservation and the genetics of population. $2^{\text {nd }}$ edition. Wiley-Blackwell. Oxford.

Alwiyah, H. Nuraini, P.P. Agung, \& Jakaria. 2016. Polymorphism stearoyl-CoA desaturase (SCD) gene and associaton with characteristics meat in Bali cattle. J. Indonesian Trop. Anim. Agric. 41(4):188195.

Anwar, S., A.C. Putra, A.S. Wulandari, P.P. Agung, W.P.B. Putra, \& S. Said. 2017. Genetic polymorphism analysis of $5^{\prime}$ untranslated region of thyroglobulin gene in bali cattle (Bos javanicus) from three different regions of Indonesia. $\mathrm{J}$. Indonesian Trop. Anim. Agric. 42(3):175184.

Brown, T.A. 2007. Genomes 3. $3^{\text {rd }}$ ed. Garland Sci. New York. 
Chung, E.R. 2014. Novel SNP in the coding region of the FTO gene is associated with marbling score in Hanwoo (Korean cattle). J. Anim. Sci. Tech. 56:27.

Hall, T.A. 2011. BioEdit: An important software for molecular biology. GERF Bull Biosci. 2(1):60-61.

Keller, I., D. Bensasson, \& R.A. Nichols. 2007. Transition-transversion bias is not universal: a counter example from grasshopper pseudogenes. PLoS Genet 3(2):0185-0191.

Khasanah, H., A. Gunawan, R. Priyanto, M.F. Ulum, \& Jakaria. 2016. Polymorphism of myostatin (mstn) promoter gene and its association with growth and muscling traits in Bali cattle. Media Peternakan 39 (2),95-103.

Marson, E.P., J.B.S. Ferraz, F.V. Meirelles, J.C.C. Balieiro, J.P. Eler, L.G.G. Figuerido, \& G.B. Mourao. 2005. Genetic characterization of European-Zebu composite bovine using RFLP markers. Genet Mol Res. 4(3):496-505.

Matukumalli, L.K., C.T. Lawley, R.D. Schnabel, J.F. Taylor, M.F. Allan, M.P. Heaton, J. O'Connell, S.S. Moore, \& T.P. Smith, TS Sonstegard, CP Van Tassell. 2009. Development and characterization of a high density SNP genotyping assay for cattle. PLoS. 4, e5350.

Nei, M., \& S. Kumar. 2000. Molecular Evolution and Phylogenetics. Oxford University Press. New York.

Pratiwi, N., Maskur, R. Priyanto, \& Jakaria. 2016. Novel SNP of calpain-1 (CAPN1) gene and its association with carcass and meat characteristics traits in bali cattle. J. Indonesian Trop. Anim. Agric. 41(3):1-6.

Purwantara, B., R.R. Noor, G. Anderson, \& H. Martinez. 2012. Banteng dan sapi Bali di Indonesia: status and forecasts. J Reprod Dom Anim. 14(1):37-41.

Sambrook, J., \& D. Russell. 2001. Molecular Cloning: a Laboratory Manual. $3^{\text {rd }}$ ed. Cold Spring Harbor Laboratory Press. New York.

Sutikno, S., R. Priyanto, C. Sumantri, \& Jakaria. 2018. Polymorphism of ADIPOQ and EDG1 genes in Indonesian beef cattle. J.
Indonesian Trop. Anim. Agric. 43(4):323332.

Tambasco, D.D., C.C.P. Paz, M.S. Tambasco, A.P. Pereira, M.M. Alencar, A.R. Freitas, L.L. Coutinho, I.U. Packer, \& C.A. Regitano. 2003. Candidate genes for growth traits in beef cattle crosses Bos taurus x Bos indicus. J Anim Breed Genet. 120(1):51-56.

Tamura, K., D. Peterson, N. Peterson, G. Stecher, M. Nei, \& S. Kumar. 2011. MEGA5: molecular evolutionary genetics analysis using maximum likelihood, evolutionary distance, and maximum parsimony methods. Mol Biol Evol. 28(10):2731-2739.

Wei, S., L. Zan, J.A. Ujan, H. Wang, Y. Yang, \& C. Adoligbe. 2011. Novel polymorphhism of the bovine fat mass and obesityassociated (FTO) gene are related to backfat thickness and longissimus muscle area in five Chinese native cattle breeds. Afr J Biotechnol 10:2820-2824. 